\title{
Correspondence
}

http://dx.doi.org/10.11646/phytotaxa.280.2.10

\section{Hanguana thailandica (Hanguanaceae): a new peat swamp forest species from Thailand}

\author{
LAHIRU S. WIJEDASA ${ }^{1,2,3}{ }^{*}$, MATTI A. NIISSALO ${ }^{1}$, VORADOL CHAMCHUMROOM ${ }^{4}$, PACHOK PUUDJAA ${ }^{4}$, \\ THAVEECHOCK JUMRUSCHAY ${ }^{4} \&$ PETER C. BOYCE 5 \\ ${ }^{I}$ Theoretical Ecology \& Modelling Lab, Department of Biological Sciences, National University of Singapore, 14 Science Drive 4, \\ Singapore 117543. \\ ${ }^{2}$ ConservationLinks, 433 Clementi Avenue 3, \#01-258, Singapore 120433. \\ ${ }^{3}$ Rimba, 18 E KampungBasung, Kuala Berang 21700, Terengganu, Malaysia. \\ ${ }^{4}$ The Forest Herbarium, Department of National Parks, Wildlife and Plant Conservation, 61, Phahonyothin Road, LadyaoChatuchak, \\ Bangkok 10900, Thailand. \\ ${ }^{5}$ Institute of Biodiversity and Environmental Conservation (IBEC), Universiti Malaysia Sarawak, 94300 Samarahan, Sarawak, \\ Malaysia. \\ *Corresponding author,E-mail: lahirux@gmail.com
}

A new species of Hanguana (Hanguanaceae), H. thailandica, is described and illustrated from Trang province, Peninsular Thailand. This is the second Hanguana species recorded in Thailand, along with the widespread helophytic H. malayana. The species is morphologically similar to Hanguana exultans and H. nitens found in swamp forests habitats in southern Peninsular Malaysia and Singapore. The conservation status of this species is accessed as Endangered according to the IUCN Red List Category and Criteria.

Keywords: Commelinales, IUCN, Peat swamp forest, Peninsular Thailand, Trang

\section{Introduction}

Hanguanaceae (Commelinales) is a small monogeneric family growing in many different forest types across South and Southeast Asia, exhibiting the highest diversity in the Sunda region (Leong-Škorničková \& Boyce 2015). A poor understanding in both its taxonomy and distribution has hampered the classification of the genus Hanguana Blume (1827: 15). The lack of clarity can be attributed to the loss upon drying of many useful field characters, historical over-reliance on poorly preserved and badly documented specimens, and very few reliable field observations (Siti Nurfazilah et al. 2011). This has led to most regional treatments such as those for Malesia and Thailand (Backer 1951, Larsen 1972) specifying the existence of single relatively common species, Hanguana malayana (Jack 1820: 25) Merrill (1915:3), across the region.

Recent taxonomic work documenting Hanguana in the field has led to the understanding that the genus is comprised of numerous ecologically discrete species, found in different forest types. This led to the results that H. malayana was recircumscribed in 2010 as a habitat specific colonial freshwater helophyte and fourteen new species were described from Peninsular Malaysia, Sarawak, Sabah and Singapore (Siti Nurfazilah et al. 2010, 2011, Mohd Fahmi et al. 2012, Niissalo et al. 2014, Leong-Škorničková \& Boyce 2015). While carrying out field work in a peat swamp forest in Trang Province, Peninsular Thailand, the authors encountered a clumping Hanguana not matching any of the forest species so far described in the genus. This overlooked species has been collected from the same location five times since 1994.

The Hanguana species we found in the peat swamp in Trang Province is morphologically similar to Hanguana exultans Siti Nurfazilah et al. (2010: 207), a species endemic to peat swamp forest in Johore, Peninsular Malaysia and H. nitens Siti Nurfazilah et al. (2010: 207), occurring in similar habitats in Johore and Singapore. However, the new species is different from $H$. nitens in having solitary stems instead of forming large rhizotomous colonies, and from both $H$. exultans and $H$. nitens in flower and inflorescence characters. We describe this new species here as Hanguana thailandica, the first Hanguana species based on material from Thailand. Hanguana thailandica is different from the only other Hanguana recorded from Thailand, Hanguana malayana (Larsen 1972) in being a solitary forest species: Hanguana malayana, in its current circumscription (Siti Nurfazilah 2010) is a massive helophyte with a floating rhizome network. Hanguana malayana s.s. is present in Thailand, but its previous circumscription in the country has been much too broad. 